\title{
Collection of Plants in situ and Conditioning of Butia lallemantii Seedlings
}

\author{
Luciana Paim $^{1}$ (D), Eduarda Avrella ${ }^{1}$ (D), Elisete Freitas ${ }^{2}$ (D), Claudimar Fior ${ }^{1}$ \\ ${ }^{1}$ Universidade Federal do Rio Grande do Sul - UFRGS, Porto Alegre/RS, Brasil \\ ${ }^{2}$ Universidade do Vale do Taquari - UNIVATES, Lajeado/RS, Brasil
}

\begin{abstract}
The objective of this study is to evaluate the survival and development of Butia lallemantii seedlings collected in situ. Seedlings were collected in Alegrete/RS, classified into four stipe diameter classes (SDC) and transplanted into polyethylene bags $(2 \mathrm{~L})$ filled with soil-based substrate, animal waste and rice husks. Evaluations were performed at four and eight months assessing survival, and leaf and root aspects after transplanting. The experiment was carried out in a completely randomized design with at least 50 plants per class. The results showed high survival rates for plants with larger stipe diameters, in addition to leaf emission, number of tillers, mature leaves, new roots and during decomposition. High number of new leaves was observed for SDC 2 and 3 (four months) and SDC 2, 3 and 4 (eight months). Therefore, greater survival and emission of vegetative structures were observed, especially in plants with higher diameter.
\end{abstract}

Keywords: conservation, restoration/rehabilitation areas, others (asexual propagation). 


\section{INTRODUCTION}

The genus Butia (Becc.) Becc. belongs to the Arecaceae family and is represented by 20 species, 19 of which occur in Brazil and 11 species are endemic. Its geographic distribution ranges from Bahia to Rio Grande do Sul (RS), with the exception of Espírito Santo and Rio de Janeiro (Leitman et al., 2015). In the southern region of Brazil, species of this genus are popularly known as "butiazeiros", and fruits are very appreciated for fresh consumption, production of liqueurs and sweets, and use of fibers for the production of recycled paper (Büttow et al., 2009). Its leaves are also used for handicraft (Geymonat \& Rocha, 2009).

However, some species of this genus are under population decline in RS, gradually disappearing due to the occupation of areas by extensive cattle breeding and expansion of crops (Soares \& Witeck, 2009). The occurrence of such species in RS, especially in the Pampa Biome, shows its adaptation to rural or open-area environments, where Butia lallemantii (Soares et al., 2014) stands out. It is popularly known as "butiá-anão" or "butiazeiro-anão", and is a conspicuous element in the sandy fields of western and southwestern RS, with greater abundance in sandstone elevations of municipalities of Alegrete, Manoel Viana and São Francisco de Assis (Deble \& Marchiori, 2006).

According to Soares et al. (2014), B. lallemantii presents morphological characteristics typical of small-size plants in relation to the other species of the genus Butia, being able to reach up to $1.0 \mathrm{~m}$ in height, showing a turfy habit with underground stipes. Fruiting occurs throughout the year, more abundantly in the summer (Soares et al., 2014). In addition, this species is in the List of Threatened Species of RS, as it suffers from the expansion of soybean crops and the monoculture of exotic trees (Soares et al., 2014; Fundação ZOO Botânica, 2014). In view of this, B. lallemantii presents characteristics relevant to the recovery of sandstone areas due to its natural occurrence and adaptability to extreme locations, with low water and nutritional availability (Soares et al., 2014; Freitas et al., 2010), in addition to being source of food for local fauna.

Most palm species may be spread through direct sowing; however, the lack of uniformity, the long period and the low germinative power of seeds have limited their propagation (Martins-Corder \&
Saldanha, 2006; Martins et al., 2007). An alternative is asexual propagation by using vegetative plant structures (Martins et al., 2007). In addition, there is lack of studies on the management of these species (Luz et al., 2011), especially with regard to the selection of suitable materials for their cultivation (Lima et al., 2006). High-quality seedlings for field development are obtained by using appropriate techniques, some of which are based on the properties of substrates (Silva et al., 2014; Navroski et al., 2015).

Paim \& Paim (2016) obtained high mortality rate $(60 \%)$ of B. lallemantii seedlings when they were directly transplanted to the field in an area with sandstone. Therefore, there is need for studies on the conditioning of B. lallemantii seedlings in order to favor the survival of plants and vegetative increase after planting in the field. Given the lack of information on the production and development of B. lallemantii seedlings, which have potential for the recovery of areas degraded by sandstones, this study aims to evaluate the survival rate and the development of Butia lallemantii seedlings collected in situ.

\section{MATERIAL AND METHODS}

This study began with the collection of $B$. lallemantii seedlings at "Fazenda Três Nascentes", located in the municipality of Alegrete/RS $\left(29^{\circ} 53^{\prime}-16^{\circ} .24^{\prime} \mathrm{S}\right.$ and $55^{\circ} 22^{\prime}-54^{\circ} .78^{\prime} \mathrm{W}$ ) in May 2015 (Figure 1A). According to the Köppen classification, the region is characterized as $C f a$ climate, subtropical mesothermic, with annual rainfalls around 1,400 $\mathrm{mm}$ and approximately $600 \mathrm{~m}$ above sea level. The climate is characterized by a period of frost, from May to August, and another with intense heat, with temperatures above $22^{\circ} \mathrm{C}$, mainly in the months of January and February (Moreno, 1961).

Six Butia lallemantii clumps with mean diameter of $1.0 \mathrm{~m}$ each in a population with mean density of 40 clumps per hectare were extracted. For the removal of clumps, soil was carefully removed $30-50 \mathrm{~cm}$ around them in order to avoid damage to seedlings. After all plants were separated from each clump, leaves and roots were pruned (Figure 1B), leaving about $5 \mathrm{~cm}$ in root length and $25 \mathrm{~cm}$ in shoot length. Then, all individuals collected from each clump were separated and counted and, according to the number of seedlings obtained, they were classified into four 


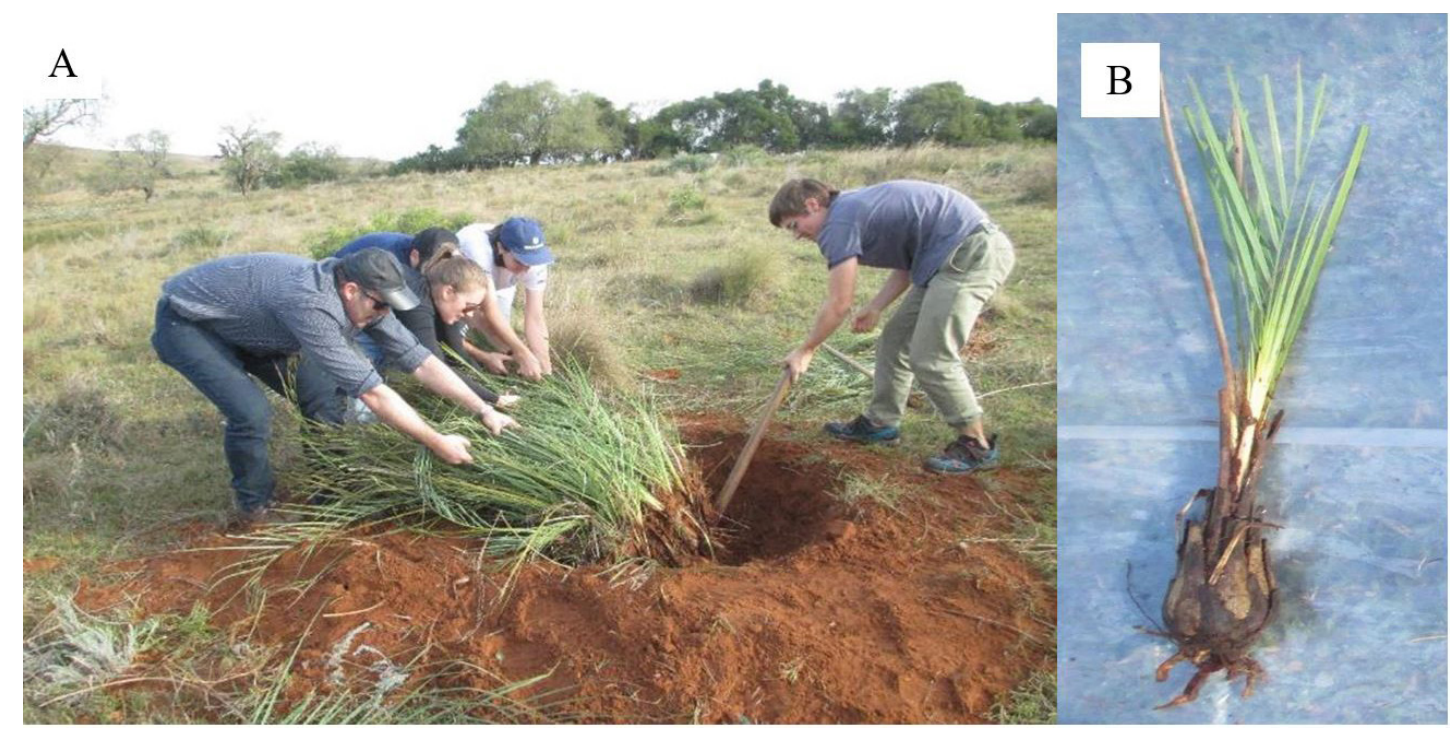

Figure 1. Collection of B. lallemantii seedlings in the city of Alegrete/RS (A) and seedlings with size of $30 \mathrm{~cm}$ after pruning of leaves and roots, leaving $25 \mathrm{~cm}$ and $5 \mathrm{~cm}$, respectively (B).

stipe diameter classes (class 1: less than $4.2 \mathrm{~cm}$, class 2: 4.21 to $6.4 \mathrm{~cm}$, class $3: 6.41$ to $9 \mathrm{~cm}$, and class 4: above $9 \mathrm{~cm}$ ) (Figure 2A, B, C and D), according to the distribution of diameters found for seedlings.

After cleansing, pruning and sorting, seedlings were placed in black polyethylene bags with capacity of $2 \mathrm{~L}$ filled with substrate composed of a mixture of sandstone soil (Quartzeneic Neosol), cattle manure and fresh rice husks (1:1:1, v/v/v/v) (Figure 2E) and were submitted to analysis at the Laboratory of Substrates of the Faculty of Agronomy - Federal University of Rio Grande do Sul, UFRGS (Table 1). Sandstone soil and cattle manure were acquired from a property near the collection site, which has an area undergoing a sandstone process. Plants were kept under shading in the morning and direct sunlight in the afternoon, with two weekly irrigations and, when necessary, removal of weeds.

Evaluations were carried out in August and December 2015, respectively, four and eight months after collection and transplanting, assessing variables survival rate, leaf appearance (green, new or dry) and root system (roots or in decomposition) for the four stipe diameter classes. At 8 months, only survival, number of tillers per seedling, and new leaves and roots were evaluated.
In the first evaluation (four months), 10 plants per stipe diameter class were randomly selected to evaluate leaf appearance (new, mature and dry) and the root system. In the final evaluation (eight months), 131 plants of class 1, 83 plants of class 2, 63 plants of class 3 and 50 plants of class 4 were analyzed, considering variables survival rate, total number of tillers, new leaves and new roots.

The experimental design was completely randomized and treatments evaluated were stipe diameter classes (class 1: less than $4.2 \mathrm{~cm}$, class 2: 4.21 to $6.4 \mathrm{~cm}$, class 3: 6.41 to $9 \mathrm{~cm}$, and class 4: above $9 \mathrm{~cm}$ ). Data were submitted to Bartlett's normality test and, after meeting the assumptions of the analysis of variance, ANOVA, followed by comparison of means by MSD (Minimum Significant Difference). Data of mature leaves, dry leaves and decomposing roots did not meet ANOVA assumptions, being transformed into $\sqrt{\mathrm{x}+0.1}$ (Equation1), and the last two factors to arcsine $\sqrt{\frac{\mathrm{x}}{10}}$ (Equation 2). Inaddition, variables related to number of tillers, new roots and new leaves did not meet ANOVA assumptions even after data transformation, and therefore were submitted to nonparametric analysis of variance using the Kruskal-Wallis test, with subsequent comparison of averages by the Dunn's test using the Sigma Plot 11.0 software. 


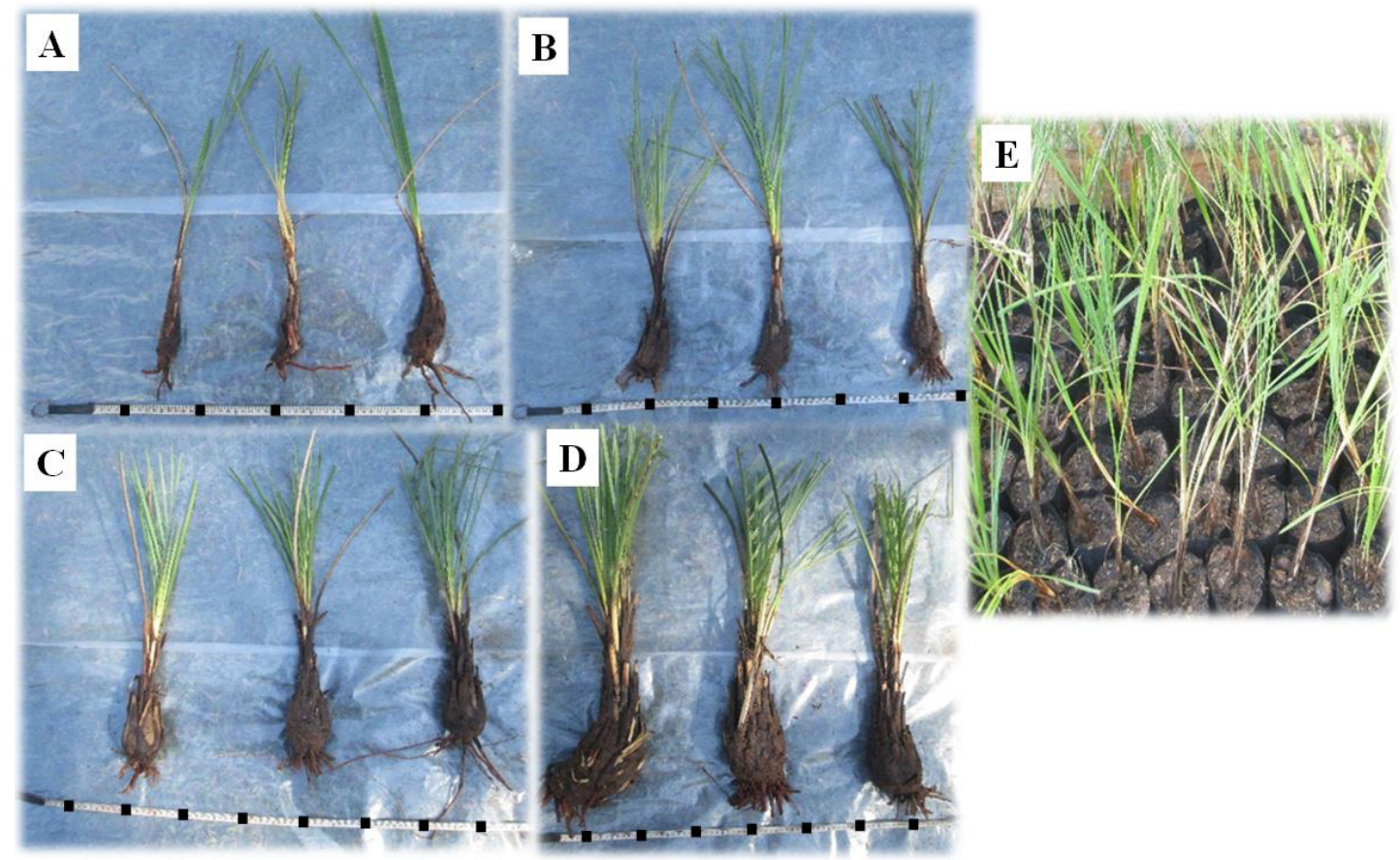

Figure 2. Classification of seedlings into four stipe diameter classes, class 1: less than $4.2 \mathrm{~cm}$ (A), class 2: 4.21 to $6.4 \mathrm{~cm}(\mathrm{~B})$, class 3: 6.41 to $9 \mathrm{~cm}(\mathrm{C})$, and class 4: above $9 \mathrm{~cm}$ (D) and conditioning of seedlings in polyethylene bags with substrate (sandstone soil + cattle manure + fresh rice husks + rice husk ash) (E).

Table 1. Physical and chemical properties of substrate composed of sandstone soil (Quartzarenic Neosol), cattle manure, fresh rice husks and rice husk ash $(1: 1: 1: 1, \mathrm{v} / \mathrm{v} / \mathrm{v} / \mathrm{v})$.

\begin{tabular}{|cc|}
$\begin{array}{c}\text { Physical and chemical } \\
\text { properties }\end{array}$ & Substrate composition \\
\hline $\mathrm{pH}\left(\mathrm{H}_{2} \mathrm{O}\right)$ & 6.83 \\
\hline $\mathrm{CE}\left(\mathrm{mS} \mathrm{cm}^{-1}\right)$ & 0.19 \\
\hline $\mathrm{DU}\left(\mathrm{kg} \mathrm{m}^{-3}\right)$ & 799.60 \\
\hline $\mathrm{DS}\left(\mathrm{kg} \mathrm{m}^{-3}\right)$ & 650.08 \\
\hline $\mathrm{UA}(\%)$ & 19.05 \\
\hline $\mathrm{PT}(\%)$ & 79.07 \\
\hline EA (\%) & 19.93 \\
\hline AFD (\%) & 27.05 \\
\hline AT (\%) & 0.5 \\
\hline AR (\%) & 31.58 \\
\hline CRA 10 (\%) & 59.13 \\
\hline CRA 50 (\%) & 32.08 \\
\hline CRA 100 (\%) & 31.58 \\
\hline
\end{tabular}

$\mathrm{pH}=$ hydrogenation potential, determined in water $1: 5(\mathrm{v} / \mathrm{v})$; $\mathrm{CE}=$ electric conductivity obtained in solution $1: 5(\mathrm{v} / \mathrm{v})$; $\mathrm{DU}=$ wet density; $\mathrm{DS}$ = dry density; $\mathrm{UA}=$ current humidity; $\mathrm{PT}=$ total porosity; $\mathrm{EA}=$ airing space; $\mathrm{AFD}=$ readily available water; $\mathrm{AT}=$ buffer water; $\mathrm{AR}=$ remaining water; CRA 10,50 and $100=$ water retention capacity under suction of 10,50 and $100 \mathrm{~cm}$ of water column determined in volumetric $(\mathrm{v} / \mathrm{v})$ basis.

\section{RESULTS AND DISCUSSION}

Aspects related to plants and the B. lallemantii population under study $B$. lallemantiiis species characterized by short height, presence of pinnate leaves and turfy stipes, forming clumps due to the emission of tillers, in which clumps are important characteristics for sustenance and nutritional capacity (Soares et al., 2014; Nair, 2010). An average of 65 plants was recorded in each clump, totaling 386 seedlings. Stipe diameter class 1 had the highest number of plants (39.7\%), followed by class $2(28.7 \%)$ and classes 3 and 4, with $17.4 \%$ and $14.2 \%$, respectively. It was also observed that small stipe diameter plants are located in the periphery of clumps; the closer to the center, the greater the diameter of seedlings.

Some plants showed signs of fruiting (dry rachides still adhered to plants). This shows that plants remain active and growing even after the emission of tillers and/or fruiting. Unlike most species of this genus, B. lallemantii produces infructescences with low number of fruits due to the low number of rachides in 
its inflorescence, which vary from 10 to 38 (Soares et al., 2014). This characteristic may be related to the need for reserves for the emission of tillers, since it is an interesting evolutionary strategy of this species that favors its perpetuation and the main characteristic that distinguishes it from most species of palm trees, which spread through seeds (Lorenzi et al., 2010).

Based on the characteristics found in clumps and plants, there is evidence that their formation starts from a seedling arising from a seed, which was probably dispersed by animals. Also, when it reaches the mature stage, the plant begins to produce fruits and emit tillers, gradually increasing the number of plants and, consequently, the area occupied by clumps.

\subsection{Analysis of the survival rate of seedlings in bags}

Considerable survival rate in both evaluation periods for classes 3 and 4 was observed, that is, plants with larger stipe diameter (Figure 3 ). The use of rice husks in the substrate formulation may have favored the survival of seedlings in bags, since they have high drainage capacity, slightly alkaline $\mathrm{pH}$ and adequate content of macronutrients $\mathrm{K}$ and $\mathrm{Ca}$, essential for the development of plants (Saidelles et al., 2009). Similarly, Paim \& Paim (2016) found high survival of $B$. lallemantii in the field of a sandstone area by using seedlings with bare roots and high stipe diameter and the application of materials such as carbonized rice husks and tanned cattle manure directly into furrows.

An ideal substrate should have $20-30 \%$ aeration space, $80-90 \%$ total porosity and $20-30 \%$ readily available water (De Boodt \& Verdonck, 1972; Kämpf, 2005; Cadahia, 1998). The formulation of the substrate used in the present study presented aeration space and total porosity values close to ideal: $19.93 \%$ and $79.07 \%$, respectively. Readily available water was shown to be adequate (27.05\%) (Table 1). These data are of great importance due to the scarcity of studies on the use of suitable substrates for the cultivation of palm trees, hindering the improvement of knowledge on the production of seedlings (Luz et al., 2011; Brahm et al., 2013).

In this sense, seedlings with greater stipe diameter and the use of organic materials in the substrate composition are important factors to be considered for the propagation of palm species (Paim \& Paim, 2016). These authors reported in their second study on survival rates and adaptation of $B$. lallemantii seedlings to a sandstone area using at the time of field planting carbonized husks and tanned cattle manure, an association with the high stipe diameter, unlike in the first study, in which the authors reported seedlings with smaller stipes and incorporation of plant remains from the place of origin.

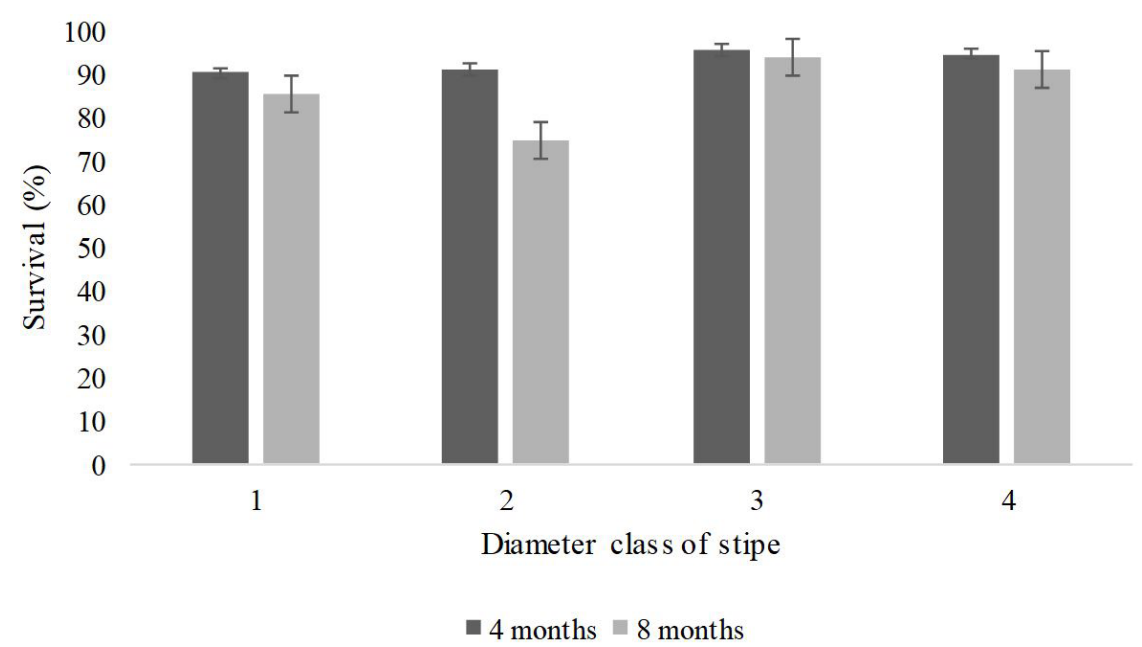

Figure 3. Survival rate of $B$. lallemantii seedlings after four and eight months of permanence in a substrate mixture (sandstone, cattle manure, fresh rice husks and rice husk ash), according to stipe diameter class (class 1: less than $4.2 \mathrm{~cm}$, class 2: 4.21 to $6.4 \mathrm{~cm}$, class 3: 6.41 to $9 \mathrm{~cm}$, and class 4 : above $9 \mathrm{~cm}$ ). 


\subsection{Evaluation of leaf appearance}

High number of leaves in plants belonging to classes 3 and 2 stipe diameter was observed, which presented tillers within four months. Class 2, however, did not differ statistically from class 1 plants (Table 2). Supposedly, younger plants, with smaller stipe diameter and reduced availability of nutrient reserves, required high investment in the emission of new leaves to compensate the demand for photo-assimilates for their survival, since plants with larger stipe diameter had higher amounts of nutrient reserves for the formation of new leaves. The increase in new leaves is important because the species under study can be found in places with low nutritional contents and absence of particle structuring in sandy soils, hindering the development of seedlings.

The variable number of mature leaves at four months was high for class 4 plants, which showed larger stipe diameter (Table 2). Stipe has great importance for palm trees, as it accumulates reserves at its base and acts in the transportation of water and nutrients, in addition to allowing the plant establishment, increasing the tolerance capacity to the action of strong winds (Salm, 2005; Nair, 2010). Thus, plants with greater stipe diameter were privileged with high availability of nutritional reserves, therefore favoring the permanence of mature leaves with green coloration for longer periods. Likewise, the Bactris gasipaes species (Kunth), a typical palm of low fertility soils, showed favorable

Table 2. Leaf appearance of $B$. lallemantii seedlings according to the number of new leaves (NL), mature leaves (ML) and dry leaves (DL) after four months, and number of total new leaves (NTNL) and tillers (NTT) after eight months of permanence in substrate according to stipe diameter class.

\begin{tabular}{ccccccc} 
Class & \multicolumn{3}{c}{ 4 months } & & \multicolumn{2}{c}{8 months } \\
\cline { 2 - 4 } \cline { 6 - 7 } DE & NL & ML & DL & & NTNL & NTT \\
\hline C1 & $4.9 \mathrm{bc}^{*}$ & $0.53 \mathrm{~b}^{*}$ & $0.53^{\text {ns }}$ & & $0.17 \mathrm{~b}^{*}$ & $0.02 \mathrm{bc}^{*}$ \\
$\mathrm{C} 2$ & $6.2 \mathrm{ab}$ & $0.90 \mathrm{a}$ & 0.52 & & $0.77 \mathrm{a}$ & $0.15 \mathrm{~b}$ \\
$\mathrm{C} 3$ & $7.5 \mathrm{a}$ & $0.83 \mathrm{ab}$ & 0.54 & & $0.81 \mathrm{a}$ & $0.28 \mathrm{ab}$ \\
$\mathrm{C} 4$ & $4.1 \mathrm{c}$ & $1.13 \mathrm{a}$ & 0.62 & & $0.82 \mathrm{a}$ & $0.50 \mathrm{a}$ \\
$\mathrm{CV}(\%)$ & 38.05 & 44.16 & 22.31 & & $* *$ & $* *$ \\
\hline
\end{tabular}

${ }^{\mathrm{ns}}=$ not significant at $5 \%$ probability; Classes $\mathrm{DE}=$ classes of stipe diameter; $\mathrm{C} 1=$ class 1 (less than $4.2 \mathrm{~cm}$ ); $\mathrm{C} 2=$ class 2 ( 4.21 to $6.4 \mathrm{~cm}) ; \mathrm{C} 3=$ class $3(6.41$ to $9 \mathrm{~cm}$ ); C4 = class 4 (greater than $9 \mathrm{~cm}$ ); $\mathrm{CV}=$ variation coefficient; ${ }^{*}$ averages followed by the same letter in the column do not differ from each other by the DMS test at $5 \%$ error probability; ${ }^{*}$ Krukall-Wallis test for non-parametric analysis of variance. vegetative development due to the characteristics of its stipe and tillers (Chávez Flores \& Yuyama, 2007).

The results regarding the number of dry leaves per plant did not show significant difference among stipe diameter classes (Table 2), which suggests that the death of these leaves is related to their natural senescence.

Cattle manure used in the substrate composition may have benefited the formation of new tillers and leaves in B. lallemantii plants during the eight months of evaluation, expressing satisfactory results for classes with the largest stipe diameters (Table 2). Thus, the development of tillers in $B$. lallemantii is very important for its survival, since it is assumed that the increase in these vegetative structures considerably increases the number of sprouts in the plant clump, favoring the asexual propagation of this species, which has turfy stem. According to Jardim et al. (2007), in asexual reproduction, sprouting with tillers has been a strategy commonly used by different palm species.

In the development of seedlings that remain for longer time in bags, the organic fraction of the substrate allows greater moisture retention and greater nutrient supply due to the mineralization of this material (Cunha et al., 2006; Costa et al., 2007). Corroborating this information, Luz et al. (2011) obtained satisfactory results using substrate composed of cattle manure for Rhapis excelsa (Thunb.) A. Henry ex Rehder seedlings. Similarly, for the Euterpe edulis Martius species, cattle manure showed to be an adequate organic material for the development of seedlings (Martins et al., 2007). However, there is need for greater attention with the use of animal waste as a substrate component due to chemical and physical instability that may negatively affect seedlings. However, the substrate composition was positive in relation to the use of organic compounds due to the low electric conductivity $\left(0.19 \mathrm{mS} \mathrm{cm}^{-1}\right)$ (Table 1), since the ideal electric conductivity range for most crops is between 0.36 and $0.65 \mathrm{mS} \mathrm{cm}^{-1}$ (Cavins et al., 2000).

\subsection{Evaluation of the root system of seedlings}

Four months after transplanting, significant variations among stipe diameter classes were observed for variables number of new roots and number of roots under decomposition, being higher than the average of class 4 diameter plants. These data are consistent with a study conducted by Tracz et al. (2009), which 
observed the presence of roots under decomposition in Bactris gasipaes (Kunth), providing favorable conditions for the formation of new roots, in which the number of remaining roots reached $10 \%$. According to size, plants tend to accumulate more nutritional reserves, which is frequently related to the age of seedlings (Fernandes et al., 2013). This information corroborates results in relation to superior responses to the largest stipe diameter class by $B$. lallemantii seedlings.

Results regarding the presence of new roots, in this study, eight months after transplanting, did not indicate significant difference among stipe diameter classes, that is, new roots were emitted, regardless of stipe diameter (Table 3).

Given the above, the transplanting of B. lallemantii plants contributed to the renewal of the root system of seedlings. This was confirmed by the higher number of new roots in comparison to decomposing roots.

Even with potential for consumption as food and the possibility of other uses, many species of the genus Butia are still unknown, which is largely due to the scarcity of scientific information on this subject. Therefore, further studies should be carried out proposing the rescue of species in situ and proper knowledge of their cultivation in order to subsidize the production of seedlings to diffuse the use of these species and, at the same time, help in the conservation of genetic resources.

Table 3. Data of the root system of B. lallemantii seedlings according to the number of new roots (NR) and roots under decomposition (RD) per plant after four and eight months of permanence in substrate according to stipe diameter class.

\begin{tabular}{|c|c|c|c|}
\hline \multirow{2}{*}{ Classes DE } & \multicolumn{2}{|c|}{4 months } & \multirow{2}{*}{$\frac{8 \text { months }}{\text { NR }}$} \\
\hline & NR & RD & \\
\hline $\mathrm{C} 1$ & $1.7 \mathrm{~b}^{*}$ & $0.42 b^{*}$ & $0.02^{\mathrm{ns}}$ \\
\hline $\mathrm{C} 2$ & $3.3 \mathrm{ab}$ & $0.42 \mathrm{~b}$ & 0.06 \\
\hline C3 & $1.4 \mathrm{~b}$ & $0.48 \mathrm{~b}$ & 0.10 \\
\hline $\mathrm{C} 4$ & $4.9 \mathrm{a}$ & $0.94 \mathrm{a}$ & 0.11 \\
\hline CV (\%) & 76.36 & 49.39 & $* *$ \\
\hline \multicolumn{4}{|c|}{$\begin{array}{l}\text { ns }=\text { not significant at } 5 \% \text { probability; Classes } \mathrm{DE}=\text { stipe } \\
\text { diameter classes; } \mathrm{C} 1=\text { class } 1(\text { less than } 4.2 \mathrm{~cm}) ; \mathrm{C} 2=\text { class } 2 \\
(4.21 \text { to } 6.4 \mathrm{~cm}) ; \mathrm{C} 3=\text { class } 3(6.41 \text { to } 9 \mathrm{~cm}) ; \mathrm{C} 4=\text { class } 4 \text { (greater } \\
\text { than } 9 \mathrm{~cm}) ; \mathrm{CV}=\text { variation coefficient; }{ }^{*} \text { averages followed by } \\
\text { the same letter in the column do not differ from each other by } \\
\text { the DMS test at } 5 \% \text { error probability; }{ }^{* *} \text { Krukall-Wallis test for } \\
\text { non-parametric analysis of variance. }\end{array}$} \\
\hline
\end{tabular}

In this context, the potential of $B$. lallemantii is highlighted; whose botanical description is quite recent (Deble \& Marchiori, 2006). It is an endemic species of the Pampa Biome and its potential has not yet been explored. Thus, information about its propagation, form of clump division and proper techniques (cleaning, pruning and classification of stipe size) after its collection are of extreme importance to guide the formation and conduction of its seedlings. Seedlings with the largest stipe diameter have vigorous formation and good capacity to be transplanted directly into the field. However, small stipe plants need to be cultivated in pot until they reach suitable size for field transplantation. Paim \& Paim (2016) reported viability of the conditioning of newly collected seedlings for later planting in the field, providing higher survival rate for plants with larger stipe diameter, since no-tillage was not satisfactory.

\section{CONCLUSIONS}

The conditioning of $B$. lallemantii plants in bags proved to be viable due to the high survival rate. The emission of vegetative structures, especially in plants with larger stipe diameter, was observed.

B. lallemantii species can be propagated by clump division using proper preparation techniques (cleaning, pruning and stipe size classification) after collection for transplantation into the field in a sandstone area.

\section{SUBMISSION STATUS}

Received: 23 aug., 2017

Accepted: 16 nov., 2017

\section{CORRESPONDENCE TO}

\section{Luciana Paim}

Departamento de Fitotecnia, Universidade Federal do Rio Grande do Sul - UFRGS, Av. Bento Gonçalves, 7712, Bairro Agronomia, CEP 91540-000, Porto Alegre, RS, Brasil e-mail: lucianappaim@bol.com.br

\section{FINANCIAL SUPPORT}

Coordenação de Aperfeiçoamento de Pessoal de Nível Superior - CAPES (001). 


\section{REFERENCES}

Brahm RU, Medeiros CAB, Cardoso JH, Reisser C. Avaliação do efeito de diferentes substratos sobre o desenvolvimento de Euterpe Edulis (Mart.) e Roystonea regia (Kunth). Revista Brasileira de Agroecologia 2013; 8(2): 148-160

Büttow MV, Barbieri RL, Neitzke RS, Heiden G. Conhecimento tradicional associado ao uso de Butiás (Butia spp., Arecaceae) no Sul do Brasil. Revista Brasileira de Fruticultura 2009; 31(4): 1069-1075. http://dx.doi. org/10.1590/S0100-29452009000400021.

Cadahia C. Fertirrigacion: cultivos hortícolas y ornamentales. Madrid: Mundi-Prensa; 1998.

Cavins TJ, Whipker BE, Fonteno WC, Harden B, Mccall I, Gibson JL. Monitoring and managing $p H$ and EC using the Pour Thru Extraction Method. Horticulture Information Leaflet 590, New 7/2000. Raleigh: North Caroline State University; 2000.

Chávez Flores WB, Yuyama K. Adubação orgânica e mineral para a produção de palmito da pupunheira na Amazônia Central. Acta Amazonica 2007; 37(4): 483-490. http://dx.doi.org/10.1590/S0044-59672007000400001.

Costa CA, Ramos SJ, Sampaio RA, Guilherme DO, Fernandes LA. Fibra de coco e resíduo de algodão para substrato de mudas de tomateiro. Revista Brasileira de Horticultura 2007; 25(3): 387-391. http://dx.doi.org/10.1590/S010205362007000300013.

Cunha AM, Cunha GM, Sarmento RA, Cunha GM, Amaral JFT. Efeito de diferentes substratos sobre o desenvolvimento de mudas de Acaciasp. Revista Árvore 2006; 30(2): 207-214. http://dx.doi.org/10.1590/S010067622006000200007 .

De Boodt M, Verdonck O. The physical properties of the substrates in horticulture. Acta Horticultare, 1972; (26): 37-44. http://dx.doi.org/10.17660/ActaHortic.1972.26.5.

Deble LP, Marchiori JNC. Butialallemantii, uma nova Arecaceae do Brasil. Balduinia 2006; (9): 1-3. http:// dx.doi.org/10.5902/2358198014032.

Fernandes AR, Matos GSB, Carvalho JG. Deficiências nutricionais de macronutrientes e sódio em mudas de pupunheira. Revista Brasileira de Fruticultura 2013; 35(4): 1178-1189. http://dx.doi.org/10.1590/S010029452013000400029.

Freitas EM, Trevisan R, Schneider AA, Boldrini II. Floristic diversity in areas of sandy soil grasslands in Southwestern Rio Grande do Sul, Brazil. Revista Brasileira de Biociências 2010; 8: 112-130.

Fundação Zoobotânica do Rio Grande do Sul - Fundação ZOO Botânica. Lista da flora gaúcha ameaçada de extinção [online]. Porto Alegre: Fundação Zoobotânica do Rio Grande do Sul; 2014 [cited 2014 Dec 8]. Available from: http://www.fzb.rs.gov.br/conteudo/4809/?Homologada_a_
nova_Lista_da_Flora_Ga\%C3\%BAcha_Amea\%C3\%A7ada_ de_Extin\%C3\%A7\%C3\%A3o

Geymonat G, Rocha N. m’Butia: ecosistema único en el mundo. Castillos: Casa Ambiental; 2009.

Jardim MAG, Santos GC, Medeiros TDS, Francez DC. Diversidade e estrutura de palmeiras em floresta de várzea do estuário amazônico. Amazônia Ciência \& Desenvolvimento 2007; 2(4): 67-84.

Kämpf AN. Produção comercial de plantas ornamentais. Guaiba: Agrolivros; 2005.

Leitman P, Soares K, Henderson A, Noblick L, Martins RC. Arecaceae in lista de espécies da flora do Brasil [online]. 2015 [cited 2015 Nov 5]. Available from: http://floradobrasil. jbrj.gov.br/jabot/floradobrasil/FB15703

Lima RLS, Severino LS, Silva MIL, Vale LS, Beltrão NEM. Volume de recipientes e composição de substratos para produção de mudas de mamoneira. Revista Ciência e Agrotecnologia 2006; 30(3): 480-486. http://dx.doi. org/10.1590/S1413-70542006000300014.

Lorenzi H, Noblick LR, Kahn F, Ferreira E. Flora Brasileira Lorenzi: Arecaceae (Palmeiras). Nova Odessa: Instituto Plantarum; 2010.

Luz PB, Paiva PDO, Tavares AR, Kanashiro S, Aguiar FF. Efeito de diferentes substratos e adubação fosfatada no crescimento de mudas de Rhapis excelsa (Thunb.) A. Henry exRehder (Palmeira-ráfia). Revista Brasileira de Horticultura Ornamental 2011; 17(1): 37-42. http:// dx.doi.org/10.14295/rbho.v17i1.715.

Martins S Fo, Ferreira A, Andrade BS, Rangel RM, Silva MS. Diferentes substratos afetando o desenvolvimento de mudas de palmeiras. Revista Ceres 2007; 54(311): 80-86.

Martins-Corder MP, Saldanha CW. Germinação de sementes e crescimento de plântulas de diferentes progêneses de Euterpe edulis Mart. Revista Árvore 2006; 30(5): 693-699. http://dx.doi.org/10.1590/S0100-67622006000500002.

Moreno JA. Clima do Rio Grande Sul. Porto Alegre: Secretaria da Agricultura do Estado do Rio Grande do Sul, Diretoria de Terras e Colonização, Secção de Geografia; 1961.

Nair KPP. The agronomy and economy of important three crops of the developing world. San Diego: Elsevier Science \& Technology Books; 2010.

Navroski MC, Araujo MM, Reiniger LRS, Muniz MFB, Pereira MO. Influência do hidrogel no crescimento e no teor de nutrientes das mudas de Eucalyptusdunnii. Floresta 2015;(45): 315-328.

Paim LP, Paim MP. Uso de mudas de Butialallemantii (Deble \& Marchiori) para recuperar áreas degradadas por arenização no município de Alegrete-RS. Revista Congrega 2016; 13: 984-994.

Saidelles FLF, Caldeira MVW, Schirmer WN, Sperandio HV. Casca de arroz carbonizada como substrato para 
produção de mudas de tamboril-da-mata e garapeira. Semina: Ciências Agrárias 2009; 30(1): 1173-1186. http:// dx.doi.org/10.5433/1679-0359.2009v30n4Sup1p1173.

Salm R. The importance of forest disturbance for the recruitment of the large arborescent palm Attalea maripa in a seasonally-dry Amazonian forest. Biota Neotropica 2005; 5(1): 35-41. http://dx.doi.org/10.1590/S167606032005000100004 .

Silva RF, Eitelwein MT, Cherubin MR, Fabbris C, Weirich S, Pinheiro RR. Produção de mudas de Eucalyptus grandis em substratos orgânicos alternativos. Ciência Florestal 2014; 24(3): 609-616. http://dx.doi. org/10.5902/1980509815745.
Soares K, Witeck L. Ocorrência de Butiacapitatae outras espécies do gênero Butia na região central do Rio Grande do Sul, Brasil. In: Geymonat G, Rocha N, editores. M'botiá: ecosistema único en el mundo. Castillos: Casa Ambiental. 2009. p. 37-41.

Soares KP, Longhi SJ, Witeck L No, Assis LC. Palmeiras (Arecaceae) no Rio Grande do Sul, Brasil. Rodriguésia 2014; 65(1): 113-139. http://dx.doi.org/10.1590/S217578602014000100009 .

Tracz AL, Wendling I, Kalil AN Fo, Santos ÁF, Quoirin MGG. Enraizamento de Perfilhos de Pupunheira (Bactrisgasipaes). Pesquisa Florestal Brasileira 2009;(58): 69-75. http://dx.doi.org/10.4336/2009.pfb.58.69. 